\title{
Enhanced biodegradation at the Landgraaf bioreactor test-cell
}

Hans Oonk (OonKAY!)

André van Zomeren (ECN)

Tristan C. Rees-White (University of Southampton)

Richard P. Beaven (University of Southampton)

Nanne Hoekstra (Stichting Deltares)

Luchien Luning (Sustec Consulting and Contracting bv) Maan Hannen (Attero)

Hans Hermkes (Attero)

Hans Woelders (Attero)

April 2013

ECN-W--14-008 


\title{
Enhanced biodegradation at the Landgraaf bioreactor test-cell
}

\author{
Hans Oonk ${ }^{\mathrm{a}, *}$, André van Zomeren ${ }^{\mathrm{b}}$, Tristan C. Rees-White ${ }^{\mathrm{c}}$, Richard P. Beaven ${ }^{\mathrm{c}}$, Nanne Hoekstra $^{\mathrm{d}}$, \\ Luchien Luning ${ }^{e}$, Maan Hannen ${ }^{f}$, Hans Hermkes ${ }^{f}$, Hans Woelders ${ }^{f}$ \\ a OonKAY!, Apeldoorn, The Netherlands \\ ${ }^{\mathrm{b}}$ ECN, Energy research Centre of the Netherlands, Petten, The Netherlands \\ ${ }^{\mathrm{c}}$ Faculty of Engineering and the Environment, University of Southampton, Highfield, SO17 1BJ, United Kingdom \\ ${ }^{\mathrm{d}}$ Stichting Deltares, Utrecht, The Netherlands \\ e Sustec Consulting and Contracting bv, Wageningen, The Netherlands \\ ${ }^{\mathrm{f}}$ Attero, Haelen, The Netherlands
}

\section{A R T I C L E I N F O}

\section{Article history:}

Received 12 October 2012

Accepted 5 March 2013

Available online 18 April 2013

\section{Keywords:}

Landfill

Sustainable

Biodegradation

Leachate

Hydrology

\begin{abstract}
A B S T R A C T
From 2001 to 2011, a bioreactor demonstration was performed in a 25,000 m $\left(8 \mathrm{~m}\right.$ deep, $3500 \mathrm{~m} \mathrm{~m}^{2}$ surface) test-cell. In this bioreactor, biodegradation was enhanced by premixing and homogenizing of waste, recirculation of leachate and aeration. Anaerobic biodegradation was completed within four years and was followed by two years of aeration. Ultimately a residue was obtained that had lost approximately $95 \%$ of its biogas potential. Biodegradation resulted in a significantly reduced leaching potential for dissolved organic carbon (DOC) and specific heavy metals. For other inorganic components, less progress was achieved. Increased flushing would be required for further reduction of the leaching potential. A significant reduction in chemical oxygen demand (COD) and ammonia $\left(\mathrm{NH}_{4}^{+}\right)$in leachate was not demonstrated during the relative short-term aeration: COD concentrations actually increased slightly and there was no effect on $\mathrm{NH}_{4}^{+}$. During the project, it became clear that moisture flow through the waste followed preferential flow paths. Therefore, attention was also paid to gain better understanding of leachate flows. From a tracer test, it was concluded that part of the waste contaminants are held in immobile blocks and are to a large extent unaffected by flow occurring in the surrounding preferential flow paths.
\end{abstract}

(c) 2013 Elsevier Ltd. All rights reserved.

\section{Introduction}

Unmanaged landfilling of waste results in risks for the local and global environment. On a global scale, methane generated as a result of degradation of organic matter contributes to global warming. On a local scale, uncontrolled release of leachate may result in the pollution of groundwater near the landfill. In an effort to control landfill emissions, managed landfills have protective measures. Landfill gas is collected, as a result of which methane emissions are reduced. During the operation of a landfill and during the post closure phase, a liner and drainage system is used to capture leachate and prevent or limit migration. Following closure of the landfill, the generation of leachate is reduced using a top-liner system. In the longer term this also limits the potential for groundwater pollution, even when the bottom liner and drainage system are no longer fully functional.

Although managed landfills represent a huge step forward compared to uncontrolled landfilling, they cannot be considered sustainable due to the long term need for resources. The dispersion

\footnotetext{
* Corresponding author. Address: OonKAY!, Fabianusstraat 12, 7333 BD, Apeldoorn, The Netherlands. Tel.: +31 555423534 .

E-mail address: hans@oonkay.nl (H. Oonk).
}

of pollutants into the environment is only prevented as long as the landfill is actively managed and the top-liner system is maintained and periodically replaced. The pollution potential of the landfill itself is not reduced in this approach and as a result, the risks of uncontrolled release of pollutants remains over the long term.

In the past decades, a significant R\&D effort has been paid to identify and develop alternative ways for managed landfilling. These alternatives are based on the control of the processes leading to pollution, rather than control of the dispersion of the pollution into the environment. One important conclusion can be drawn from all international research: once biologically stabilised, the pollution potential of organic waste is significantly reduced (e.g., van Zomeren et al., 2006). The two main options for organic stabilisation are: leachate recirculation (e.g. Yazdani et al., 2006; Barlaz et al., 2010) and landfill aeration (e.g. Ritzkowski and Stegmann, 2008; Ritzkowski, 2011). However biological stabilisation by itself will not reduce concentrations of all contaminants. Some inorganic contaminants, e.g. $\mathrm{Cl}^{-}$and under anaerobic conditions also $\mathrm{NH}_{4}^{+}$, are not degraded or immobilised. So when reduction of the pollution potential is the objective, addition of clean water and flushing might be considered to reduce these inorganic contaminants as well. When pollution potential of the waste is sufficiently 
decreased, landfill aftercare can be simplified and costs for leachate infiltration, flushing or aeration might be off-set by costs savings on longer terms.

This article describes a pilot for waste treatment in a bioreactor test-cell at the Landgraaf-landfill. In this bioreactor, biodegradation is enhanced by recirculation of leachate. The expectation was that complete biodegradation has a beneficial effect on the pollution potential of the waste. Originally the objectives of the pilot were to demonstrate that degradation of organic waste can be significantly accelerated in a bioreactor and to explore the effects of accelerated decomposition on the pollution potential of the waste. During the project, it became clear that moisture flow through the waste is highly heterogeneous. Therefore additional activities were defined, such as to develop an understanding of flow processes in landfills and to investigate heterogeneity, and the extent to which waste in the bioreactor was uniformly treated by the bioreactor technology applied.

\section{Test-cell design and initial waste characterisation}

\subsection{Operational strategy}

The proposed strategy to promote biodegradation, within the Landgraaf test cell, was as follows.

\section{Construct the test-cell with a homogeneous mix of wastes}

Biodegradation was promoted by using a mixture of the following waste types: biologically active wastes, (e.g. water treatment sludges) that enable a rapid start to biodegradation; inorganic wastes with buffering capacity (e.g. demolition wastes) that prevent initial acidification of the waste and inhibition of methanogenesis; organic wastes that contain large amounts of organic materials that are partially converted to biogas, with the remainder able to immobilise heavy metals; and inert materials that provide mechanical strength to the waste and ensure porosity is retained.

During the filling of the pilot cell, the following ratios were aimed for: $3-5 \mathrm{wt} \%$ (weight percent of total weight) biologically active wastes, $5-10 \mathrm{wt} \%$ of buffering wastes; $30-40 \mathrm{wt} \%$ organic wastes and $40-50 \mathrm{wt} \%$ of inert wastes. In the end, this composition was realised as well.

Although these waste types are generally found in landfills, the Landgraaf test-cell was different, because materials were intensively mixed prior to landfilling. For this purpose, different waste were separately stockpiled prior to deposition in the test-cell. From each stockpiles fixed amounts of waste were taken, summing up to few loads of a dumper. This was mixed using a loader and subsequently deposited in the landfill cell.

\section{Recirculate leachate to promote biodegradation}

At the start of the project, maintaining leachate recirculation at a high rate was considered to be the best guarantee for enhanced biodegradation. Although sufficient moisture content is prerequisite for biodegradation, previous experiences indicated that saturated conditions might inhibit biodegradation (Oonk and Woelders, 1999; Wens et al., 2001). Furthermore, the importance of moisture movement for biodegradation was demonstrated in on lab-scale (e.g. Klink and Ham, 1982). Based on earlier experiences with leachate recirculation (reported in Oonk et al., 2004), the decision was made to maintain a continuous recycle rate of $600-1500 \mathrm{~mm}\left(0.6-1.5 \mathrm{~m}^{3} / \mathrm{m}^{2}\right)$ per year (which is $2-5$ times the annual average natural infiltration in the Netherlands).

Following anaerobic conversion of organic matter, aerate the waste

The aeration of waste was not considered in the original design of the bioreactor cell. For air injection, the lower leachate infiltra- tion drains were used (see chapter 3 for a description of the infiltration system). This approach had its limitations, especially when it came to monitoring the effects of the aeration. $200 \mathrm{~m}^{3}$ per hour was pumped into the waste for a period of two years, equating to $200 \mathrm{~m}^{3}$ per $\mathrm{Mg}$ dry waste. This is twice the amount reported to be required for in situ stabilisation of old landfills (van Vossen and Heijer, 2009).

From 2005 onwards, it was determined that ammonium $\left(\mathrm{NH}_{4}^{+}\right)$ concentrations in leachate would be one of the key contaminants to abate. For this reason, $\mathrm{NH}_{4}^{+}$was removed from the recirculated leachate by nitrification. Nitrification was done in a biorotor, which is a common used unit for biological water treatment. In a biorotor, leachate is aerated by rotating, undulating discs, which also serve as a substrate for bacteria growth. The nitrified leachate was subsequently fed back to the waste for denitrification.

\subsection{Infrastructure}

The Landgraaf test cell was constructed in 2000-2002. The cell contained $25,000 \mathrm{Mg}$ (ton) of wet waste, had a surface area of $\sim 3500 \mathrm{~m}^{2}(50 \times 70 \mathrm{~m})$, with maximum depth of $8 \mathrm{~m}$. Fig. 1 depicts the test-cell.

The test-cell was located on top of existing layers of waste and was formed by building $5.5 \mathrm{~m}$ high clay dikes. The bottom and sides of the cell were fully lined with $2 \mathrm{~mm}$ high density polyethylene (HDPE). On top of the bottom liner, nine parallel leachate collection pipes were placed in a $0.5 \mathrm{~m}$ thick layer of drainage sand. Upon filling the cell, two injection systems comprising perforated HDPE-pipes were dug into the waste at two levels: the lower system was at about $3 \mathrm{~m}$ from the top of the waste; the upper system was at the top of the waste (about $50 \mathrm{~cm}$ below the waste upper surface). The waste was capped with a $25 \mathrm{~cm}$ thick layer of wood-chips directly on top of the waste (to aid gas collection), followed by a $30 \mathrm{~cm}$ thick layer of clay (to reduce loss of methane and minimise the effect of precipitation). On top of the clay, a mixture of uniform sand and compost was laid to promote methane oxidation. Outside the bioreactor, a $40 \mathrm{~m}^{3}$ water tank was used to store leachate coming from the test-cell. From the storage tank, leachate could either be recirculated back into the bioreactor or discharged off site to sewer. When considered useful, clean water could be added to the system. A biorotor was added in 2005 to nitrify leachate in the storage tank. Six fully penetrating gas wells were brought up from the top of the drainage sand layer, when landfilling progressed. Extra attention was paid to compaction of the waste around the wells and during construction. The gas wells were connected to a gas extraction system and gas was collected from the waste at a slight suction pressure. Eight discrete level piezometers were installed in the waste, two of them $1 \mathrm{~m}$ above the bottom liner; six of them about $3 \mathrm{~m}$ above the bottom liner.

\subsection{Waste characterisation}

Waste was analysed prior to mixing and deposition in the landfill. Samples were taken from each individual stream and moisture content and loss on ignition (LOI) were measured. Household waste and commercial waste was sorted into fractions, with moisture content and LOI measured for each fraction. The composite samples of the initial waste was characterised in a pH stat leaching test. Individual samples were characterised in batch leaching tests. Following the tracer test, the pilot cell was excavated (see chapter 4). During the excavation, waste samples were taken for measurement of moisture content and ignition loss, respiration tests, leaching tests and a manual sorting out of larger parts of remaining organic material. Full results of waste analysis and specification of methods used are described in the digital appendix. 


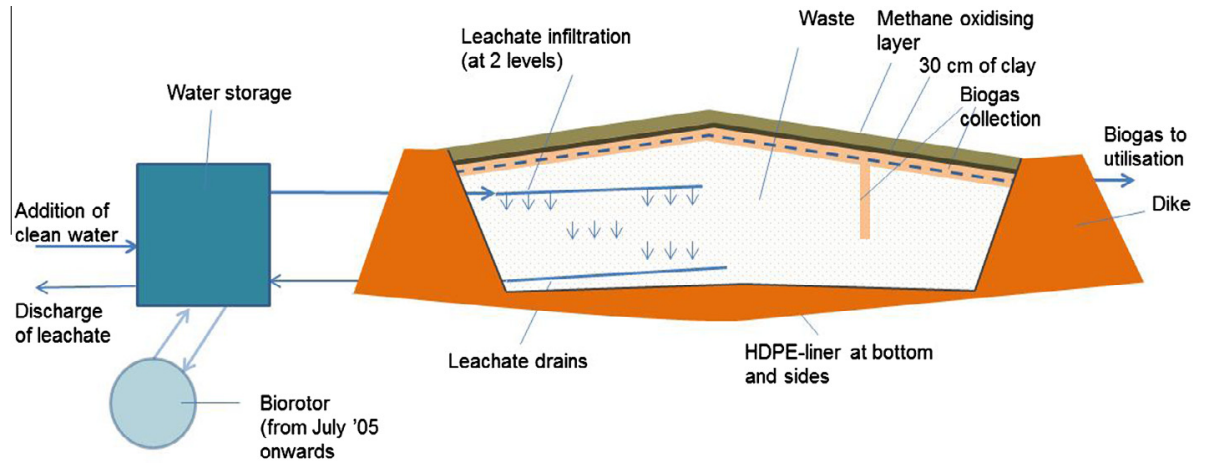

Fig. 1. Sketch of the bioreactor test-cell (not at scale).

Table 1

Recirculation, water addition and leachate discharge at the Landgraaf bioreactor.

\begin{tabular}{|c|c|c|c|c|c|c|c|c|}
\hline \multirow[t]{2}{*}{ Period } & \multirow[t]{2}{*}{ From } & \multirow[t]{2}{*}{ To } & \multicolumn{3}{|c|}{ Recirculation of leachate } & \multirow{2}{*}{$\frac{\text { Addition of water }}{\left(\mathrm{m}^{3}\right)}$} & \multirow{2}{*}{$\frac{\text { Discharge }}{\left(\mathrm{m}^{3}\right)}$} & \multirow{2}{*}{$\frac{\text { Accumulation }}{\left(\mathrm{m}^{3}\right)}$} \\
\hline & & & $\left(\mathrm{m}^{3}\right)$ & $\left(\mathrm{m}^{3} /\right.$ day $)$ & $(\mathrm{mm} / \mathrm{yr})$ & & & \\
\hline \multicolumn{9}{|c|}{ Precipitation during construction } \\
\hline & August ‘01 & February ‘02 & & & & 1275 & & \\
\hline \multicolumn{9}{|c|}{ 1. Recirculate and add } \\
\hline $1 \mathrm{a}$ & May 6th ‘02 & October 24th '02 & 5600 & 33 & 3000 & 870 & 180 & 680 \\
\hline $1 \mathrm{~b}$ & October 24th ‘02 & January 20th ‘03 & 2900 & 33 & 3000 & 890 & 0 & 890 \\
\hline $1 \mathrm{c}$ & January 20th ‘03 & April 3rd ‘03 & 2700 & 37 & 3400 & 990 & 0 & 990 \\
\hline $1 \mathrm{~d}$ & April 3rd ‘03 & August 27th ‘03 & 3000 & 21 & 1900 & 280 & 0 & 280 \\
\hline \multicolumn{9}{|c|}{ 2. Discharge off site, add and recirculate } \\
\hline $2 \mathrm{a}$ & August 27th ‘03 & February 20th '04 & 2400 & 14 & 1300 & 590 & 610 & -10 \\
\hline $2 b$ & February 20th ‘04 & July 6th ‘04 & 3500 & 25 & 2300 & 670 & 380 & 280 \\
\hline $2 c$ & July 6th ‘04 & December 7th '04 & 2900 & 19 & 1700 & 560 & 450 & 110 \\
\hline $2 d$ & December 7th '04 & August 23rd ‘05 & 3300 & 13 & 1100 & 1100 & 880 & 180 \\
\hline \multicolumn{9}{|c|}{ 3. Recirculate only } \\
\hline 3 & August 23rd ‘05 & April 25th ‘06 & 2500 & 10 & 900 & 0 & 3 & -3 \\
\hline
\end{tabular}

\subsection{Monitoring}

The performance of the bioreactor was intensively monitored. Water-flows (leachate recirculation, discharge of leachate off-site, addition of clean water) were monitored on a daily basis. Acidity $(\mathrm{pH})$, redox $(\mathrm{eH})$, electro-conductivity $(\mathrm{EC})$, biological oxygen demand (BOD), chemical oxygen demand (COD), and ammonia $\left(\mathrm{NH}_{4}^{+}\right)$in leachate was determined on a weekly basis. Leachate samples were analysed in a more complete way every two months. Piezometers were sampled three times per year. Amounts of gas collected was measured continuously and registered on a daily basis; methane and $\mathrm{CO}_{2}$-concentrations in the gas were measured weekly. During the period of aeration, monitoring was less intensive, with only the occasional leachate analysis. The effectiveness of aeration was measured by determining the gas composition in the piezometers.

After ending landfill aeration, additional efforts were made to characterise the waste using methods that can be considered experimental, when applied to landfills. A number of sub-surface geophysical screening techniques were tested to investigate waste heterogeneity and variations in water content, and a full-scale tracer test was undertaken to recover contaminant transport properties of the waste (Rees-White et al., 2011, 2012).

\section{Operation}

The waste was collected during the summer of 2001 and kept stored at a depot, prior to mixing and deposition in the test-cell (from August to November 2001). The cell-cover was finished in April 2002. Gas collection commenced in March 2002, and leachate recirculation started in May 2002.

Leachate recirculation was operated over 12 or $24 \mathrm{~h}$ cycles. For the first hour clean water was added to fill up the water storage tank. In the 2 nd hour, $20 \mathrm{~m}^{3}$ of water was fed into the leachate injection system. The remaining time leachate collected in the basal drains was fed back to the storage tank.

Operation of the bioreactor is summarised in Table 1 . In the first 16 months, clean water was added to the system, while recirculating leachate. No leachate was discharged off site.

At the end of period 1d, accumulation of water was negligible and no fresh water had to be added to keep the system running. From August 2003 onwards, operation of the bioreactor was changed to a more cyclic mode (indicated in Table 1 as periods 2a to $2 d$ ). Each individual cycle lasted for about half a year and consisted of three steps: (i) first recirculation was stopped and excess leachate was drained; (ii) subsequently recirculation was started again and clean water was added in order to keep the system running and as a third step; (iii) leachate was recirculated without clean water being added.

From August 2005 until August 2006 leachate was only recirculated (period 3). From August 2006 to August 2008 air was injected at a rate of $200 \mathrm{~m}^{3}$ per hour, through the infiltration system at intermediate level. Operation of the test-cell was stopped in August 2008, after which geophysical surveys were conducted and a tracer-test was performed. 


\section{Excavation}

The test-cell was excavated in July 2011. During this process, 19 samples of waste were taken for leaching tests and respiration tests (see Section 5.4). Samples were taken from a cross-section that was dug out. Using an excavator, larger samples of about $0.25-0.5 \mathrm{~m}^{3}$ were taken from this cross-section. Subsequently from each sample $8-12 \mathrm{~kg}$ of material was handpicked and taken to the lab. Larger objects $(>10 \mathrm{~cm})$ were left out from this hand-picked sample. About $3 \mathrm{~m}^{3}$ of excavate waste was sorted out manually, characterising the amount of these larger objects. Total amount of larger objects was about $23 \mathrm{wt} \%$ of total wet waste: $1 \mathrm{wt} \%$ paper; $3 \mathrm{wt} \%$ wood; $6 \mathrm{wt} \%$ soft plastics; $6 \mathrm{wt} \%$ hard plastics; $7 \mathrm{wt} \%$ other inerts (stones, textiles).

Photographs of the waste upon excavation can be found in a digital appendix. Visually, the plastics fraction dominated the looks of the material. The waste seemed to be very homogeneous and seemed to have degraded in a homogeneous way. However, spread throughout the waste, larger pieces of organic materials could still be found, e.g. wood, folded newspapers, packs of paper. The waste did not feel moist. No intermediate water tables were observed. Only the lowest point at the base of the landfill a head of about $10-20 \mathrm{~cm}$ of leachate was observed, which was removed using a tanker car.

Upon excavation there were areas of waste, mainly in the upper horizons, which appeared to be cemented by a hard clog like material. Waste samples from these areas had to be chiselled out. The concretions appeared to occur mainly in horizontal layers where parts of the waste had a rusty-brown appearance. The hypothesis is that aerobic conditions in the waste led to iron-cementation. In anaerobic waste, iron may exist as soluble Fe(II) species or as deposited FeS. Upon aeration the reduced species can be oxidised to less soluble $\mathrm{Fe}(\mathrm{III})$ species (e.g. $\mathrm{Fe}(\mathrm{OH})_{3}$ ). This oxidation and precipitation mechanism seems a plausible explanation for the observed cementation of the waste and is comparable to the cementation of grains of sand in natural iron ore deposits.

The systems for leachate injection and collection and the system for gas-collection appeared to be fully operational. All pipes were intact, without any signs of damage and there was no evidence of scaling or other deposits in the drainage system (Beaven et al., 2013). All perforations in the leachate injection pipes were clean. The layer of woodchips on top of the waste was intact, without visible signs of degradation. The layer still maintained a structure that provided high pore volume. Finally there were no visible signs of damage or degradation to the liner-system.

\section{Results and discussion}

All monitoring data are available in a digital appendix to this article. Further modeled interpretation of these data is provided by White and Beaven (2013), in response to a Landfill Modeling Challenge set by Beaven (2009) on the Landgraaf test-cell.

\subsection{Biodegradation of organic material}

\subsubsection{The initial amount of dry organic matter}

Based on the waste analyses, the amounts of dry matter and organic dry matter in the test-cell are estimated in Tables 2 and 3.

Table 3 shows that most organic material comes with household waste and commercial waste. Table 2 gives the origin of the organic material from these streams. When it is assumed that wood and textiles hardly degrade (as was validated during excavation of the waste, and also observed on a lab-scale by Wang et al., 2011 ) and organics, paper and cellulose degrade by about $80 \%$, an average dissimilation under favourable conditions of $50 \%$ can be expected. This implies that about $1900 \mathrm{Mg}$ of organic dry material (ODM) can be considered actually degradable. Assuming a biogas generation of $0.75 \mathrm{Nm}^{3}$ per $\mathrm{kg}$ of dry organic material dissimilated, total biogas potential is estimated to be 1.4 million $\mathrm{Nm}^{3}$ ( 801 per kg dry matter).

\subsubsection{Degradation under anaerobic conditions}

From March 2002 onwards, biogas was collected. Fig. 2 gives the amount of biogas collected, both in $\mathrm{Nm}^{3}$ per hour and as $\mathrm{Nm}^{3}$ cumulative.

In total $894,000 \mathrm{Nm}^{3}$ of biogas was collected. Biogas collection increased immediately after realisation of the system for landfill gas collection. When leachate recirculation was started, biogas collection was already at a level of about $40 \mathrm{Nm}^{3}$ per hour. Biogas collection peaked at about $120 \mathrm{~m}^{3}$ per hour in June/July 2002 and afterwards slowly decreased again. At the end of the anaerobic period, biogas collection was negligible.

\subsubsection{Diffuse emissions of biogas}

Part of the organic material might have been degraded, without products of decomposition being collected as biogas. Diffuse emissions were not measured and was estimated as follows: (i) during the bioreactor demonstration in Wijster (Oonk and Woelders, 1999), biodegradation during stockpiling of wastes and filling of the cell was estimated to be $5 \%$ of the biogas potential, based on flux-box measurements of $\mathrm{CO}_{2}$ and $\mathrm{CH}_{4}$-emissions from the waste.

Table 2

Organic dry matter (ODM), organic carbon $\left(\mathrm{C}_{\text {org }}\right)$ and organic nitrogen in household waste $(\mathrm{HW})$ and commercial waste $(\mathrm{CW})$.

\begin{tabular}{|c|c|c|c|c|c|c|}
\hline & $\begin{array}{l}\text { Fraction in } \\
\mathrm{HW} / \mathrm{CW}(\%)\end{array}$ & $\begin{array}{l}\text { ODM in fraction } \\
\text { (wt\% wet waste) (\%) }\end{array}$ & $\begin{array}{l}\text { ODM in HW/CW } \\
\text { (wt\% wet waste) (\%) }\end{array}$ & $\mathrm{C}_{\mathrm{org}}$ in $\mathrm{HW} / \mathrm{CW}(\%)$ & $\mathrm{C}: \mathrm{N}$ & $\begin{array}{l}\mathrm{N} \text { in } \mathrm{HW} / \mathrm{CW} \\
\text { (wt\% in wet waste) (\%) }\end{array}$ \\
\hline \multicolumn{7}{|l|}{ A: Household waste } \\
\hline Organic materials & 14 & 44 & 6 & 2.5 & 20 & 0.12 \\
\hline Paper & 26 & 36 & 9 & 3.7 & 175 & 0.02 \\
\hline Textiles & 1 & 65 & 1 & 0.3 & 150 & 0.00 \\
\hline Wood & 11 & 87 & 10 & 3.8 & 300 & 0.01 \\
\hline Paper pulp & 1 & 61 & 1 & 0.2 & 175 & 0.00 \\
\hline Inerts & 47 & 0 & 0 & & & 0 \\
\hline Total household waste & & & 27 & 10.5 & & 0.16 \\
\hline \multicolumn{7}{|l|}{ B: Commercial waste } \\
\hline Organic materials & 13 & 25 & 3 & 1.3 & 20 & 0.07 \\
\hline Paper & 35 & 39 & 14 & 5.5 & 175 & 0.03 \\
\hline Textiles & 1 & 72 & 1 & 0.3 & 150 & 0.00 \\
\hline Wood & 2 & 90 & 2 & 0.7 & 300 & 0.00 \\
\hline Paper pulp & 3 & 58 & 2 & 0.7 & 175 & 0.00 \\
\hline Inerts & 46 & 0 & 0 & & & 0 \\
\hline Total commercial waste & & & 21 & 8.5 & & 0.10 \\
\hline
\end{tabular}


Table 3

Composition of the waste in the pilot: dry matter (DM), organic dry matter (ODM) and moisture.

\begin{tabular}{|c|c|c|c|c|c|c|}
\hline & Waste (Mg) & Water content (wt\%) & Dry matter (Mg) & Moisture (Mg) & ODM in dry matter (wt\%) & ODM (Mg) \\
\hline Household waste & 9000 & 41 & 5300 & 3700 & 45 & 2300 \\
\hline Commercial waste & 3000 & 52 & 1400 & 1600 & 36 & 600 \\
\hline Shredder waste & 4800 & 22 & 3800 & 1100 & 10 & 380 \\
\hline Street cleansing residues & 4700 & 22 & 3700 & 1000 & 10 & 370 \\
\hline Molding sand & 1300 & 1 & 1300 & 13 & 1 & 13 \\
\hline Demolition waste & 1900 & 17 & 1600 & 330 & 5 & 80 \\
\hline Biosludges & 380 & 32 & 250 & 120 & 10 & 25 \\
\hline \multirow[t]{2}{*}{ Total } & 25,200 & 31 & 17,300 & 7800 & 21 & 3800 \\
\hline & & & & \multicolumn{2}{|c|}{ Total ODM in waste: } & $15 \%$ \\
\hline
\end{tabular}

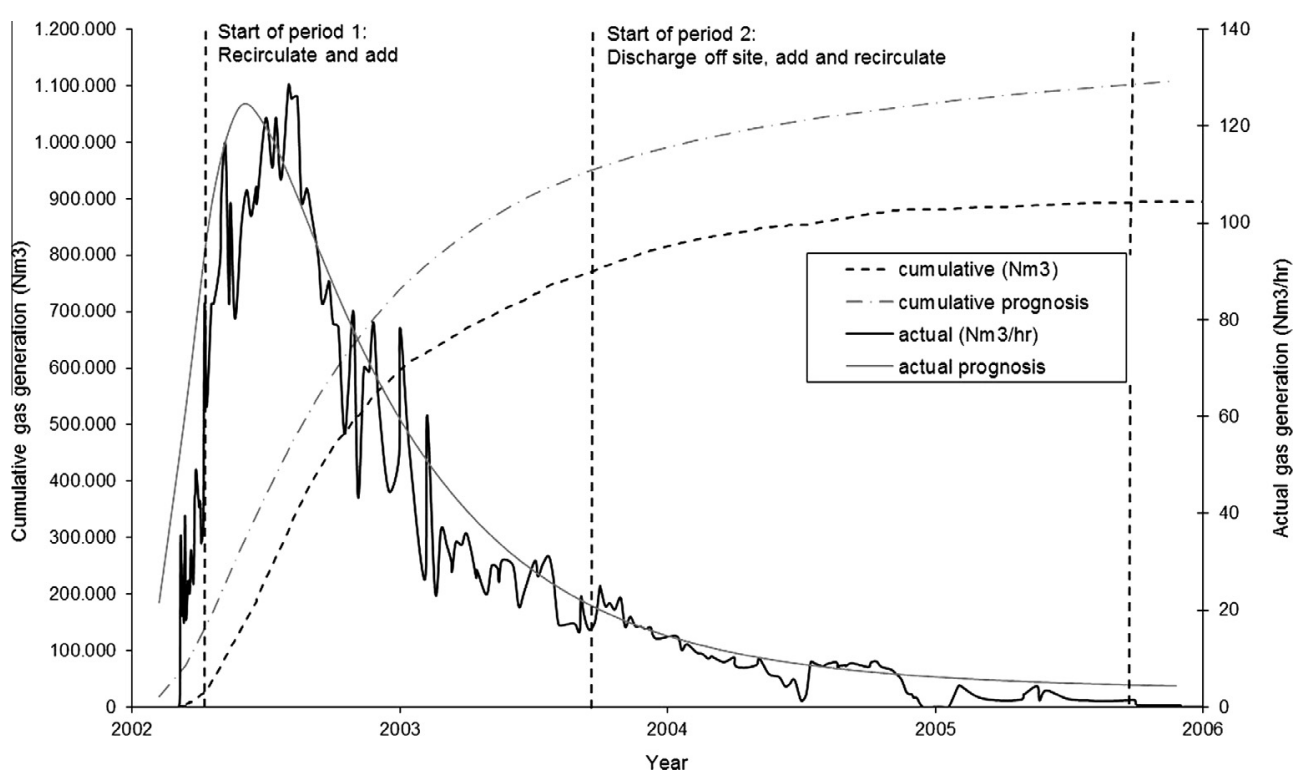

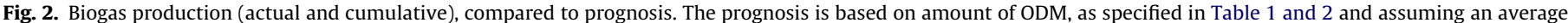

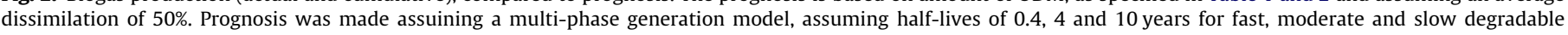
material.

The wet organic residue in Wijster was smaller in size and contained more putrescibles. So it seemed more biodegradable than the waste in Landgraaf and this $5 \%$ might be a high-end estimate for Landgraaf. Assuming 1-5\% biodegradation during stockpiling and filling implies $14,000-70,000 \mathrm{~m}^{3}$ of biogas lost; (ii) The cell was filled in November 2001, after which it took $3 \frac{1}{2}$ month for gas collection to be effective. With gas collection in place and prior to leachate infiltration, $20-30 \mathrm{~m}^{3}$ per hour could be collected. Assuming the gas production already being at this level immediately after the cell was filled, results in an estimated loss of $100,000-200,000 \mathrm{~m}^{3}$ of biogas; (iii) With gas collection in place, efficiency may not have been $100 \%$. Due to the clay seal on top of the waste and the relatively large number of gas wells in the cell ( 1 well per $1000 \mathrm{~m}^{2}$ ) it can be expected that gas collection is significantly higher than the $45-60 \%$, which is normally achieved on Dutch landfills with state of the art landfill gas collection (Oonk, 2012). During the project methane emission measurements showed that methane emissions were negligible (see digital Appendix). This indicates that the combined efficiency of methane collection and oxidation was $100 \%$. Attempts to quantify methane oxidation through ${ }^{13} \mathrm{C}$ analyses, were not successful. The amount of methane lost and subsequently oxidised could therefore not be assessed. Assuming a collection efficiency of $80 \%$ at minimum, gas losses in the operational stage are $200,000 \mathrm{~m}^{3}$ at maximum. Total diffuse emissions of biogas can be estimated as the sum of the separate contributions mentioned above and are in the order of magnitude of $100,000-500,000 \mathrm{~m}^{3}$.

\subsubsection{Degradation due to aeration}

From August 2006 to August 2008, the test-cell was aerated. A disadvantage of aerating the waste in this way, is that exhaust air is emitted through the cap to the atmosphere in an uncontrolled diffuse way. As a result, quantitative monitoring of amounts of $\mathrm{CO}_{2}$ produced and biodegradation achieved under aerobic conditions was not possible. In the piezometers, the composition of air was periodically measured. In most piezometers and on all occasions, significant amounts of $\mathrm{O}_{2}(>10 \mathrm{vol} \%)$ were measured. This suggests that distribution of injected air was good and that large parts of the waste were aerated. Concentrations of $\mathrm{CO}_{2}$ varied between 0.2 and $33 \mathrm{vol} \%$, with the majority of measurements between 1 and $15 \mathrm{vol} \%$. Occasionally high concentrations of methane were observed, indicating that some anaerobic degradation was still occurring. Based on these gas analyses a rough estimation can be made of biodegradation. Assuming the sum of methane and $\mathrm{CO}_{2}$ concentrations in the gas being $1-5 \mathrm{vol} \%, 50-$ $250 \mathrm{Mg}$ ODM was removed in two years of aeration. Aeration also had an effect on leachate quality: the ratio of COD and EC went up again after start of aeration (see also Fig. 3).

\subsubsection{Biodegradability of the residue}

Upon excavation, samples were taken and analysed in a respiration and fermentation test. Both respiration and fermentation were measured during 21 days $\left(\mathrm{RI}_{21}\right.$ and $\left.\mathrm{GP}_{21}\right)$. While performing the respiration test, respiration over 4 days $\left(\mathrm{RI}_{4}\right)$ was also determined. The results are listed in Table 4 . 


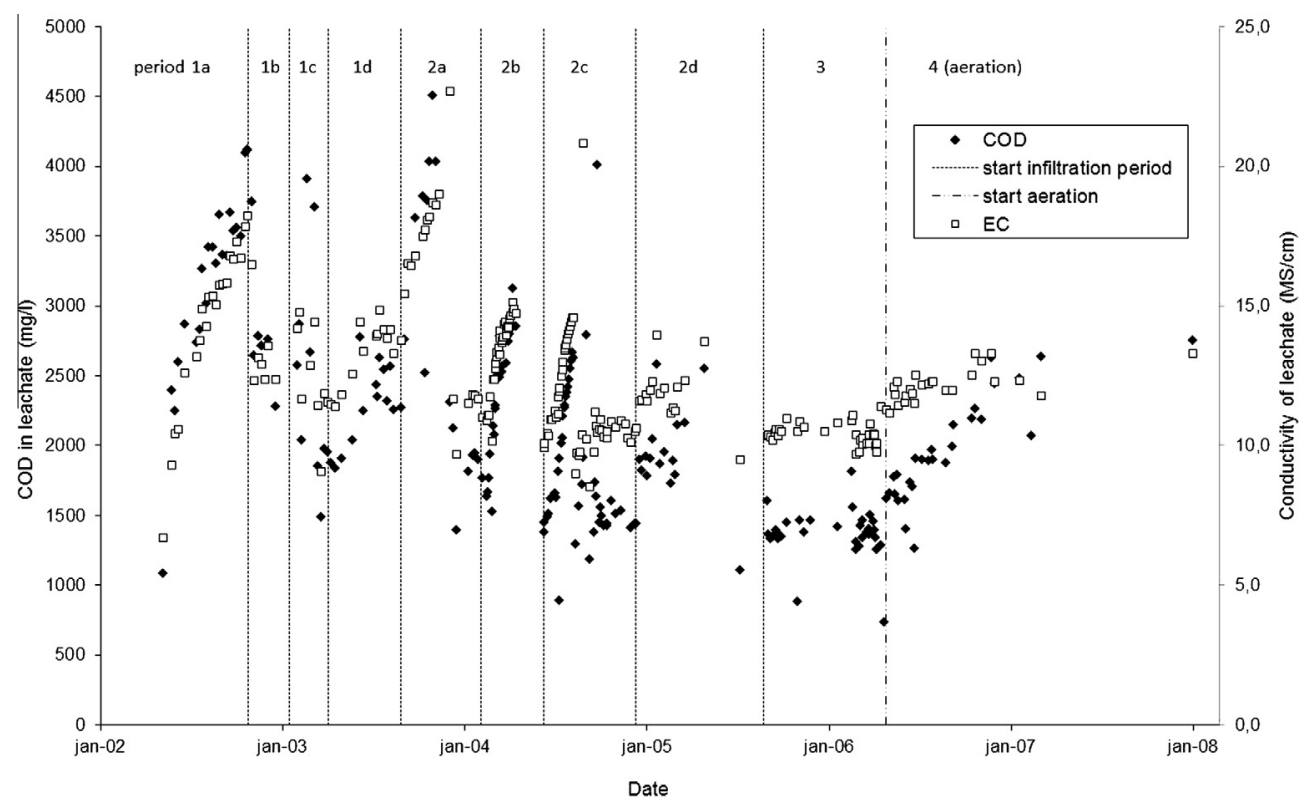

Fig. 3. Development of concentrations of COD in leachate and EC. For a time-table of the various infiltration periods, see Table 3.

Table 4

Biogas potential as removed in a respiration test $\left(\mathrm{RI}_{21}\right.$ and $\left.\mathrm{RI}_{4}\right)$ and a fermentation test $\left(\mathrm{GP}_{21}\right)$. Results refer to analyses on samples after separation of larger objects during sampling and removal of some inerts during sample preparation.

\begin{tabular}{llll}
\hline & $\mathrm{RI}_{21}(\mathrm{l} / \mathrm{kg} \mathrm{dm})$ & $\mathrm{GP}_{21}(\mathrm{l} / \mathrm{kg} \mathrm{dm})$ & $\mathrm{RI}_{4}\left(\mathrm{mg} \mathrm{O}_{2} / \mathrm{g} \mathrm{dm}\right)$ \\
\hline Number of samples & 8 & 3 & 8 \\
Mean & $<5.3$ & $<1.6$ & $<2.3$ \\
Min - max & $<2.8-7.6$ & $<0.8-3.0$ & $<1.4-3.6$ \\
\hline
\end{tabular}

Tests were performed on the fine fraction of the waste. Since this fraction will contain a high proportion of the biodegradable material, the values presented in Table 4 may be an overestimation of the $\mathrm{RI}_{21}, \mathrm{RI}_{4}$ and $\mathrm{GP}_{21}$ of the total waste. However, it should also be noted that, after 21 days, respiration for most samples was still not completed. The values in Table 4 are, therefore, an underestimation of full respiration and biogas potential. When it is assumed that the overestimation outbalances the underestimation, values in Table 4 might be a fair indicator of actual remaining biogas potential. This means that biogas potential of the waste is reduced from about 801 per kg dry matter (based on an estimate of biogas potential in the original waste in Table 5) to 5.31 per kg dry matter (dm).

The $\mathrm{RI}_{4}$ and $\mathrm{GP}_{21}$ are comparable to the values obtained at the aerobic landfill at Kuhstedt after six years of aeration. Here a somewhat lower $\mathrm{RI}_{4}$ was measured of $1.2 \mathrm{~g} \mathrm{O}_{2}$ per $\mathrm{kg} \mathrm{dm}$ and a some- what higher $\mathrm{GP}_{21}$ of 3.71 per $\mathrm{kg} \mathrm{dm}$ (Ritzkoswki and Stegmann, 2008). Values obtained for Landgraaf are in compliance with values proposed for landfills to be released from aftercare in Germany: $\mathrm{RI}_{4}<2.5 \mathrm{mg} \mathrm{O} / \mathrm{g} \mathrm{dm}$ and $\mathrm{GP}_{21}<10 \mathrm{l} / \mathrm{kg} \mathrm{dm}$ (Stegmann et al., 2006).

\subsubsection{Conclusions on biodegradation}

Based on the values above, a material balance can be made for the organic dry matter in the bioreactor. The remaining amount of biodegradable organic matter can be calculated from the difference between the amount of biodegradable amount of organic matter in the waste, the amount collected as biogas, purged with leachate, emitted in a diffuse way and converted under aerobic conditions. Table 5 gives the material balance and compares the result with the amount, based on the remaining biogas potential, as measured in the $\mathrm{RI}_{21}$-test.

Table 5 shows that calculated amounts of ODM remaining are in agreement with amounts obtained from waste sampling. However uncertainties in the material balance are quite large, mainly due to uncertainties in diffuse emissions and the amount removed by aerobic conversion. Table 5 does indicate that over $90 \%$ reduction of biodegradable organic material was achieved during leachate recirculation. So anaerobic bioreactor technology seems to be able to achieve a rapid and far-going biological stabilisation of organic material.

Table 5

Material balance for organic dry matter (ODM).

\begin{tabular}{|c|c|c|}
\hline & ODM (Mg) & Explanation \\
\hline In waste & 3800 & See Table 2 \\
\hline Biodegradable & 1900 & Assuming $50 \%$ of ODM to be actually biodegradable \\
\hline Collected as biogas & 1200 & $894,000 \mathrm{~m}^{3}$ of biogas collection. Conversion of $1 \mathrm{~kg}$ ODM yields $0.75 \mathrm{Nm}^{3}$ of biogas \\
\hline Discharged with leachate & 5 & $2500 \mathrm{~m}^{3}$ discharged with an average COD of $2000 \mathrm{mg} / \mathrm{l}$ \\
\hline Diffuse emissions & $130-670$ & $\begin{array}{l}\text { Based on an estimation } 100,000-500,000 \mathrm{~m}^{3} \text { biogas loss and assuming } 1 \mathrm{~kg} \text { ODM yields } \\
0.75 \mathrm{Nm}^{3} \text { of biogas }\end{array}$ \\
\hline Aerobic conversion & $50-250$ & Based on estimation, see text \\
\hline Remaining biodegradable (based on mass balance) & $0-500$ & $\begin{array}{l}\text { Present in waste minus collected as biogas, discharged, diffusively emitted and aerobically } \\
\text { converted }\end{array}$ \\
\hline Remaining biodegradable (based on the $\mathrm{RI}_{21}$-test) & 120 & $\begin{array}{l}\text { Based on waste sampled. } 5.3 \mathrm{~m}^{3} \text { per } \mathrm{Mg} \mathrm{DM} * 17,300 \mathrm{Mg} \text { DM. Conversion of } 1 \mathrm{~kg} \text { ODS yields } \\
0.75 \mathrm{Nm}^{3} \text { of biogas }\end{array}$ \\
\hline
\end{tabular}




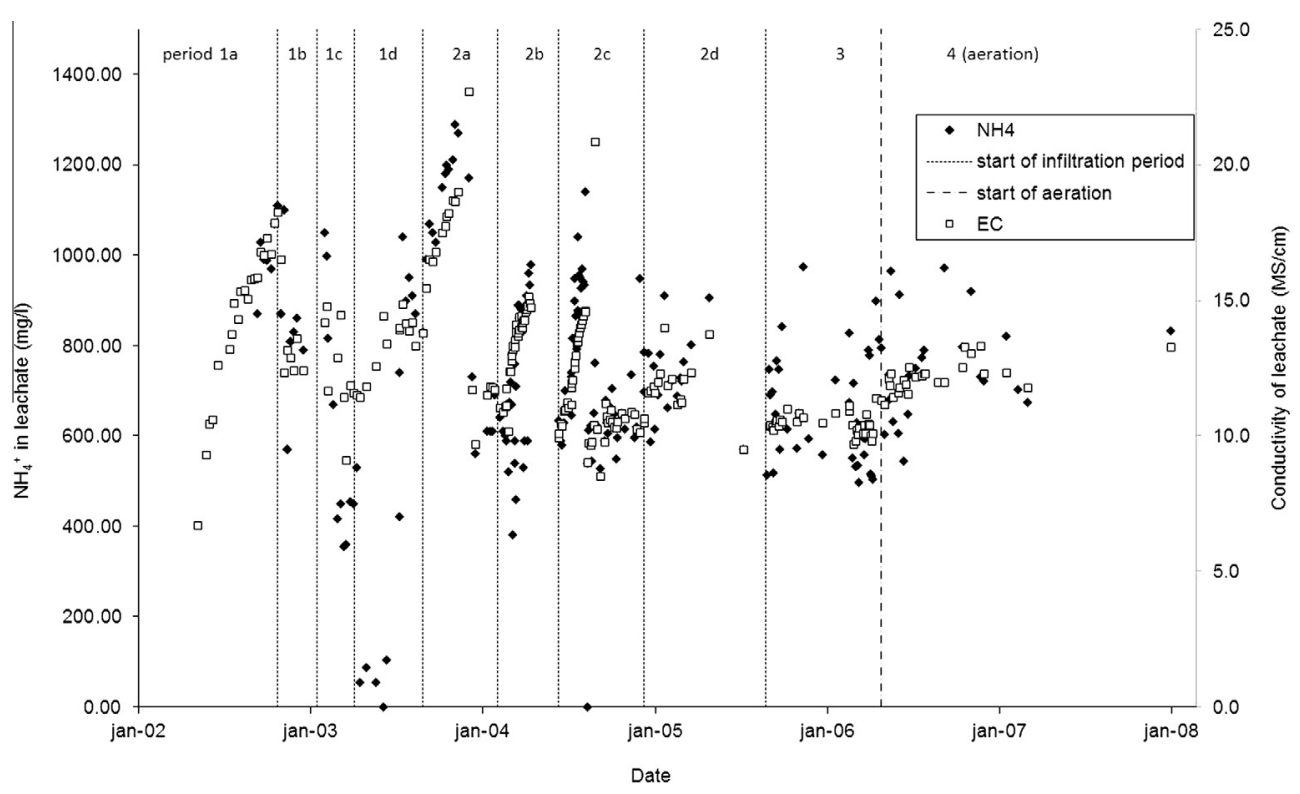

Fig. 4. Development of $\mathrm{NH}_{4}^{+}$-concentrations in leachate and Ec. For a time-table of the various infiltration periods, see Table 3.

Table 6

Material balance for organic nitrogen.

\begin{tabular}{|c|c|c|}
\hline & $\begin{array}{l}\text { Amount } \\
\text { of } N(\mathrm{~kg})\end{array}$ & Explanation \\
\hline In waste & 22,000 & Assuming $0.16 \mathrm{wt} \%$ in wet household waste and $0.10 \mathrm{wt} \%$ in wet commercial waste \\
\hline Discharged & 1650 & $2500 \mathrm{~m}^{3}$ discharged at $800 \mathrm{mg} \mathrm{NH}_{4}^{+} / \mathrm{l}\left(\sim 660 \mathrm{mg} \mathrm{NH}_{4}^{+}-\mathrm{N} / \mathrm{l}\right)$ \\
\hline Conversion in biorotor & 2800 & 1000 days $* 10 \mathrm{~m}^{3}$ per day $* 280 \mathrm{~g} \mathrm{NH}_{4}^{+}-\mathrm{N} / \mathrm{m}^{3}$ removed \\
\hline In waste at the end of the test & 17,500 & Based on mass balance: initial amount minus amount discharged and amount converted in the biorotor \\
\hline In leachate in waste & 18,000 & $12,000 \mathrm{~m}^{3}$ Water in the bioreactor $* 1500 \mathrm{~g} \mathrm{NH}_{4}^{+}-\mathrm{N} / \mathrm{m}^{3}$ measured in piezometers \\
\hline In mobile leachate & $1200-6000$ & $10-50 \%$ Of total amount of leachate $* 1000 \mathrm{~g} \mathrm{NH}_{4}^{+}-\mathrm{N} / \mathrm{m}^{3}$ in leachate in basal drain, so $1200-6000 \mathrm{~m}^{3} * 1 \mathrm{~kg} \mathrm{NH} 4-\mathrm{N} / \mathrm{m}^{3}$ \\
\hline
\end{tabular}

\subsection{Development of leachate quality}

\subsubsection{COD and electrical conductivity}

Leachate composition, within the bioreactor, varied significantly throughout the test period. Fig. 3 gives the concentrations of COD and EC as an example. The intention of enhanced biodegradation is to improve leachate quality through degradation of dissolved organic carbon (DOC) in the leachate, and the immobilisation of other pollutants (heavy metals). In addition to these mechanisms, concentrations are influenced by the addition of clean water and drainage of leachate.

For both COD and EC a gradual decline in concentrations can be observed, from the start of the project until the end of the anaerobic period. $\mathrm{EC}$ is largely determined by $\mathrm{Cl}^{-}$and to a lesser extent to components such as $\mathrm{NH}_{4}^{+}$. Since $\mathrm{Cl}^{-}$is not generated, degraded or immobilised, changes in EC will largely be the result of the addition of clean water and drainage of leachate. COD concentrations determined by formation and degradation as well. When it is assumed that the addition and drainage has similar effect on COD and EC, the change in ratio of COD and EC can be used to estimate formation and degradation of COD. Upon recirculation, the COD/EC-ratio decreased by about $25 \%$. With COD concentrations in the leachate being reduced from about $3000 \mathrm{mg} / \mathrm{l}$ to $1500 \mathrm{mg} / \mathrm{l}$, this means that about half of the decrease in COD can be attributed to degradation or immobilisation. During aeration, COD concentrations and the ratio of COD/EC significantly increased again. This increase in COD upon a relative short term of aeration is consistent with reports from aeration tests in Germany, where an initial increase in CODconcentration was observed upon aeration (Ritzkowski, 2011).

\subsection{2. $\mathrm{NH}_{4}^{+}$}

Correlation of $\mathrm{NH}_{4}^{+}$concentrations in the leachate and EC are shown in Fig. 4. The ratio of both is constant throughout the test. This suggests that $\mathrm{NH}_{4}^{+}$degradation or generation was negligible, and concentrations were only affected by the purging of leachate and the addition of clean water. After 2005, a decrease in $\mathrm{NH}_{4}^{+}$ was expected, as a result of nitrification in the biorotor. Surprisingly, this was not observed. Table 6 compares the amount of $\mathrm{N}$ removed by denitrification in the biorotor, the amount in pore-water in the waste and the amount in the amount of leachate in the test cell, what is assumed to be mobile. The amount of nitrogen removed in the biorotor is significant, compared to the amount in the mobile part of the leachate, so some effect was expected here.

\subsection{Hydrological aspects}

Evidence from a number of sources indicated that moisture flow through the waste in the test cell followed preferential flow paths. As the mechanism of fluid flow is crucial to the understanding of a bioreactors performance, additional investigations were undertaken (i.e. the tracer test and geophysics) to obtain more quantitative information on the nature and effect of fluid flow.

\subsubsection{Comparison of leachate analyses from piezometers and basal drain}

An early indication of preferential flow paths was obtained from the analysis of leachate sampled from the piezometers in comparison to samples of leachate draining from the basal collection layer. Fig. 5 shows that the EC of leachate from the piezometers is 50 


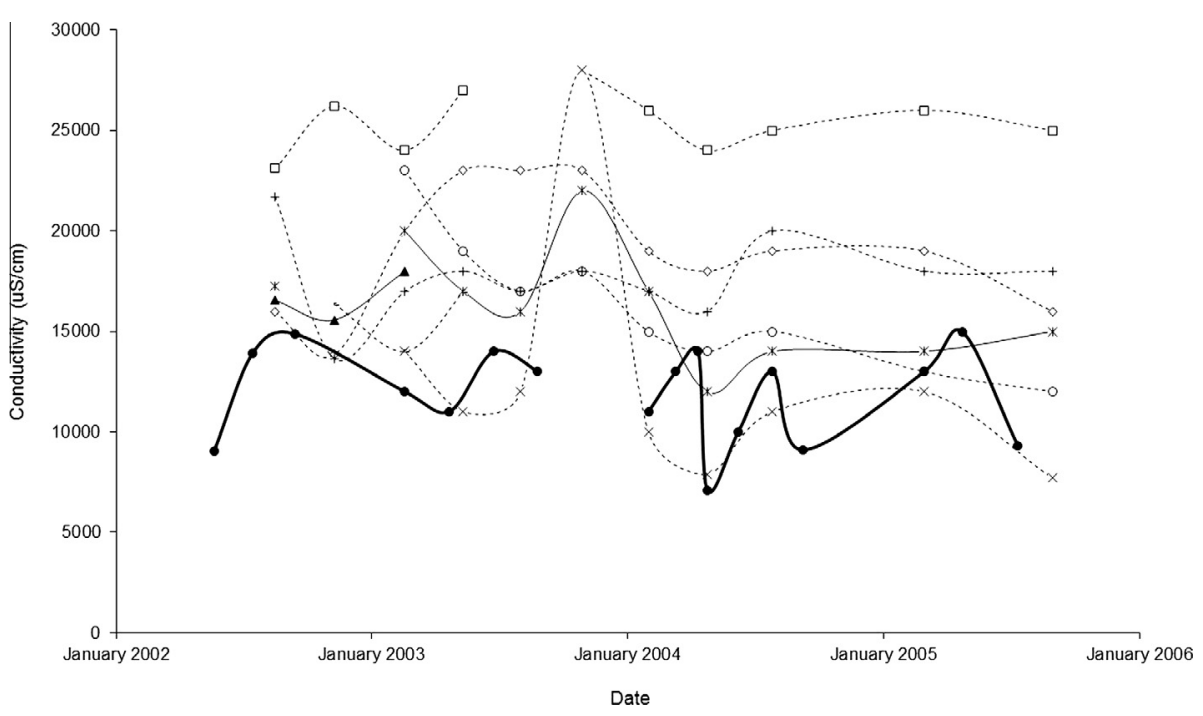

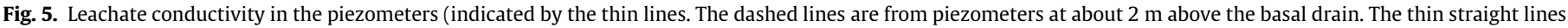
are from piezometers, just above the basal drain), compared to conductivity of leachate in basal drain (thick straight lines).
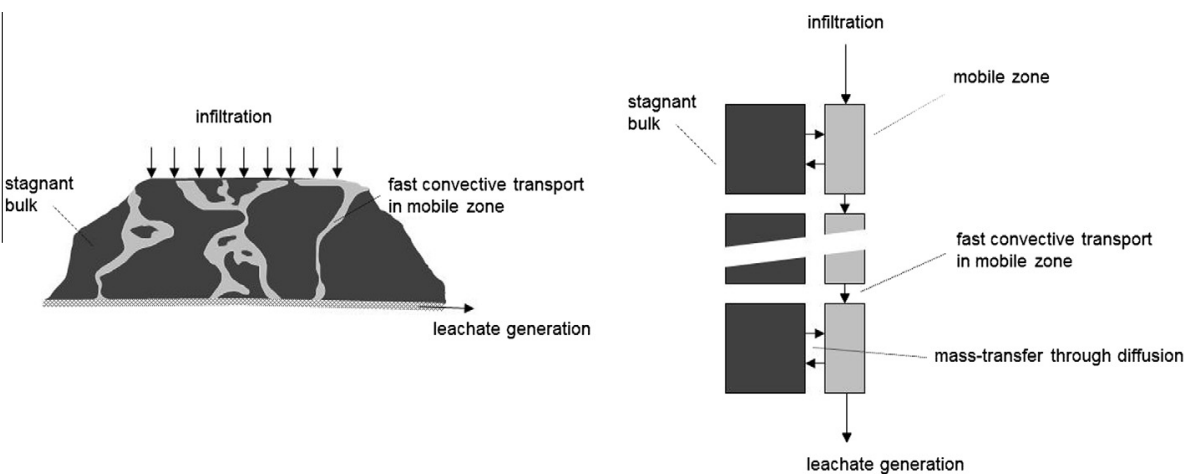

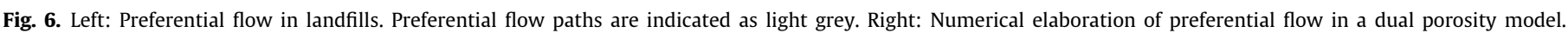


flow paths, through diffusion.

$150 \%$ higher than the EC of the basal drain leachate. This trend is repeated for COD, $\mathrm{BOD}, \mathrm{Cl}^{-}$and $\mathrm{NH}_{4}^{+}$.

The implication of these results, is that moisture in the bioreactor is not homogeneous in composition. This variation in concentrations can be explained through preferential flow routes and the adoption of a dual porosity flow system, which has previously been proposed as an appropriate model for flow in landfills (e.g. Rosqvist and Destouni (2000), Beaven et al. (2003), Laner et al. (2011), see also Fig. 6). In such a system, water flows preferentially through a relative small part of the waste. In a preferential channel, a relative high $\mathrm{L} / \mathrm{S}$ ratio is achieved and pollutants are flushed out relatively fast. Pollutants from the remainder of the waste are only released by diffusion. The overall result is a significant reduction of pollution in the leachate in the basal drain, compared to concentrations in large parts of the waste.

5.3.2. Concentrations in leachate upon draining and addition of water

A further indication of preferential flow paths was obtained during the leachate drain and water addition cycles. When leachate was drained, concentrations of contaminants gradually increased (see Fig. 7). This is again in line with expectations, based on preferential flow (see above): when the test-cell is drained, the more mobile water with low concentration is drained first.
As flow rates decrease, there is more of an opportunity for leachate concentrations to be more representative of concentrations in the less -mobile zones.

When fresh water was subsequently added, concentrations decreased again. Decrease in concentrations was much faster than expected, when moisture would be spread homogeneously through the waste. If the latter would be the case, addition of a few hundred $\mathrm{m}^{3}$ of clean water to the waste, containing over $10,000 \mathrm{~m}^{3}$ of moisture would only decrease concentrations by a few percent. In reality, concentrations are almost halved, so a much smaller volume of water was affected. E.g., in the period of April 13 rd to 16 th $2004,422 \mathrm{~m}^{3}$ of clean water was added, resulting in a reduction of $\mathrm{Cl}^{-}$in the leachate from 1600 to $780 \mathrm{mg} / \mathrm{l}$. This indicates that only $400 \mathrm{~m}^{3}$ of water. out of the total of $10,000 \mathrm{~m}^{3}$ of moisture in the bioreactor, was immediately affected by addition of clean water.

\subsubsection{Geo-electrical sounding}

Additional tools were tested to characterise moisture distribution in the waste: electromagnetic resonance, ground-radar, seismic tests and geo-electrical sounding (see also Hoekstra et al., 2009). Geo-electrical sounding proved to be the most interesting technique. Using geo-electrical sounding, distribution of resistivity 


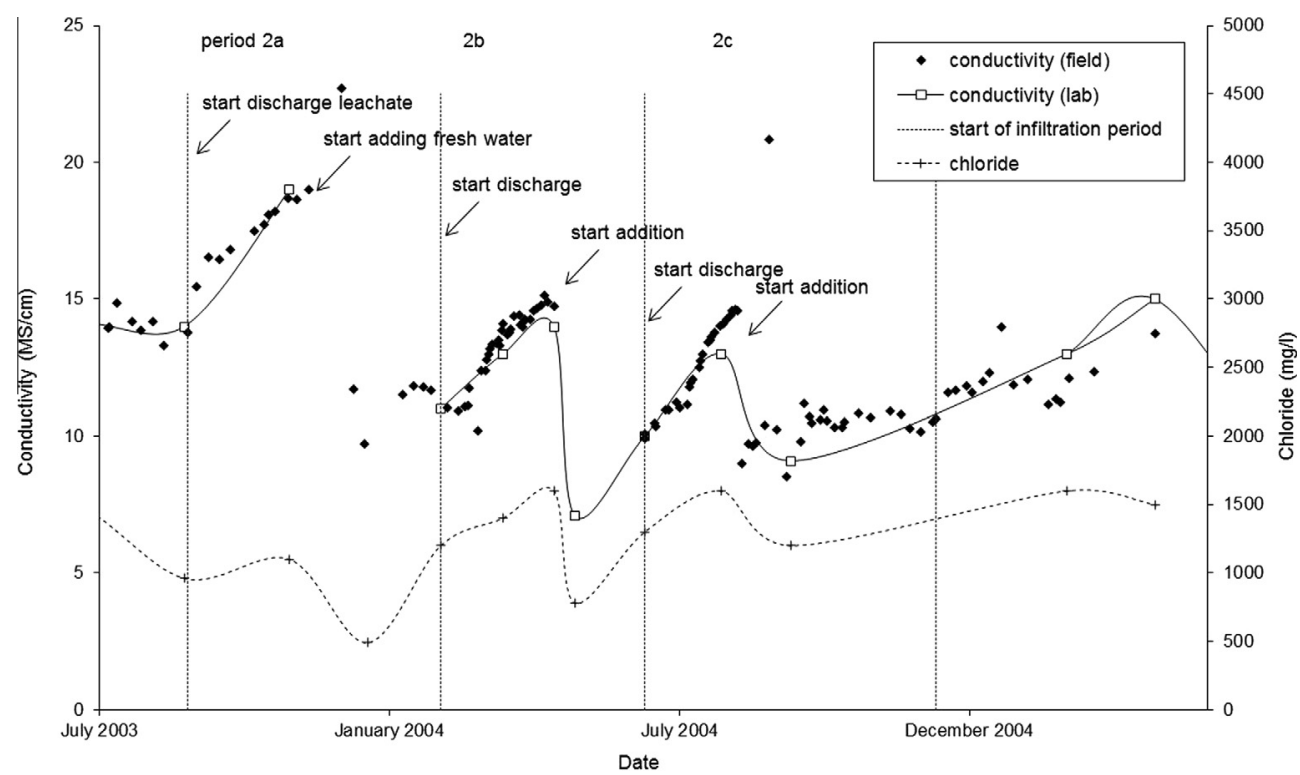

Fig. 7. Variation of conductivity and $\mathrm{Cl}^{-}$concentrations in leachate as a result of leachate discharge and subsequent addition of fresh water.
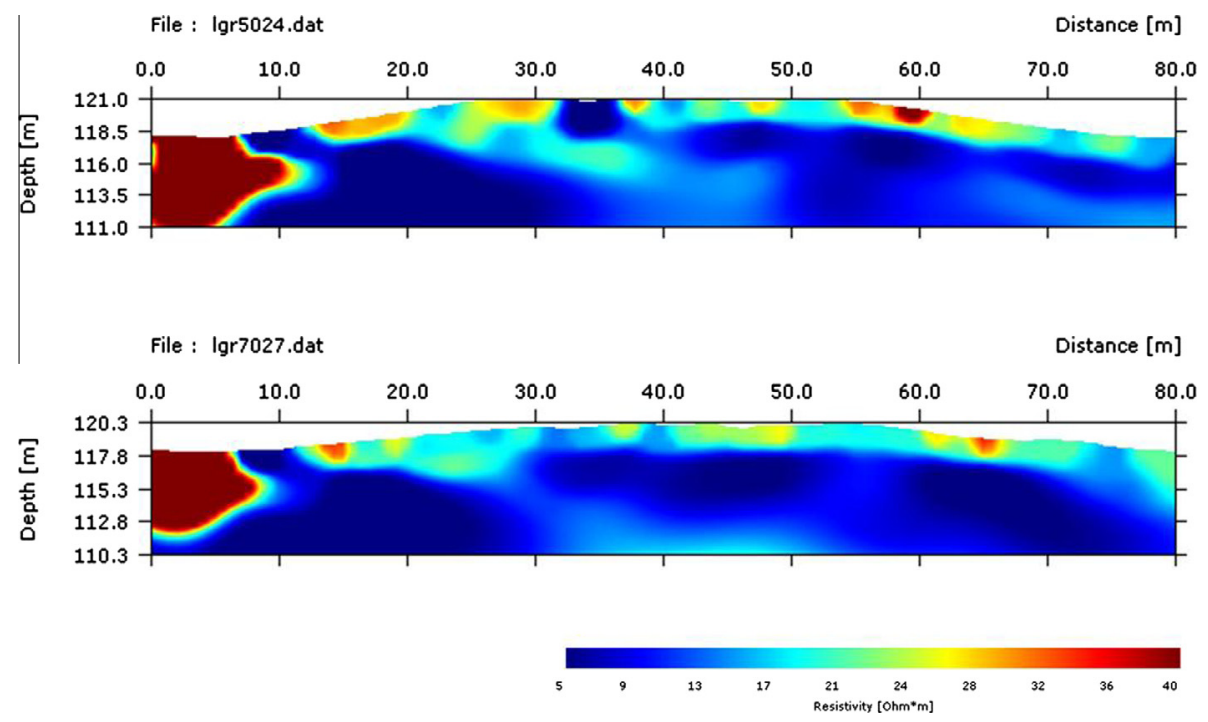

Fig. 8. Example two neighbouring profiles of resistivity, as obtained from geo-electrical sounding.

was obtained at five cross-sections in the waste. Examples of two neighbouring cross-sections are shown in Fig. 8. All five crosssection are given in the digital appendix and compared there with the results of analyses of leachate in piezometers.

Fig. 8 shows that resistivity is not homogeneously distributed in the test-cell. There are two limitation for the application of geoelectrical sounding: (i) its resolution is limited (as discussed in the context of landfills by Jolly et al., 2011). The method gives only information on average resistivity for larger parts of waste. The resolution might be in the order of magnitude of about one to few $\mathrm{m}^{3}$ at the top of the waste, but decreases rapidly at greater depths; (ii) resistivity is not only determined by moisture content, but also by moisture composition and by e.g. metal objects in the waste itself. However despite the problems with interpretation, an important conclusion is that the resistivity in the cell is not homogeneously distributed. Regions with low resistivity, moderate and high resistivity can be distinguished. Two neighbouring crosssections also have a high degree of similarity. This is an indication that a geo-electrical sounding does not produce some random pattern and the result does reflect some physical reality in the testcell. Since the waste itself was homogenized upon filling of the test-cell, the most logical explanation are differences in moisture content and moisture composition, throughout the test-cell.

\subsubsection{Tracer-test}

Following the recirculation and aeration trials, the test cell was drained. This occurred approximately 5 years after the original recirculation trials. At that time, landfill settlement of the top cover had reduced the ability of the cell to shed surface water, resulting in rainwater infiltration and a further dilution of leachate in the cell. Between November 2010 and April 2011, a 'fill and draw' tracer test was carried out with the aim of characterising the saturated contaminant transport properties of the waste in the cell. The technique involves saturating in situ waste from the bottom up with water and then, normally following a pause, draining the landfill. Full details of the test are provided by Rees-White et al. 




Fig. 9. Tracer (bromide and rhodamine WT) concentrations measured during abstraction.

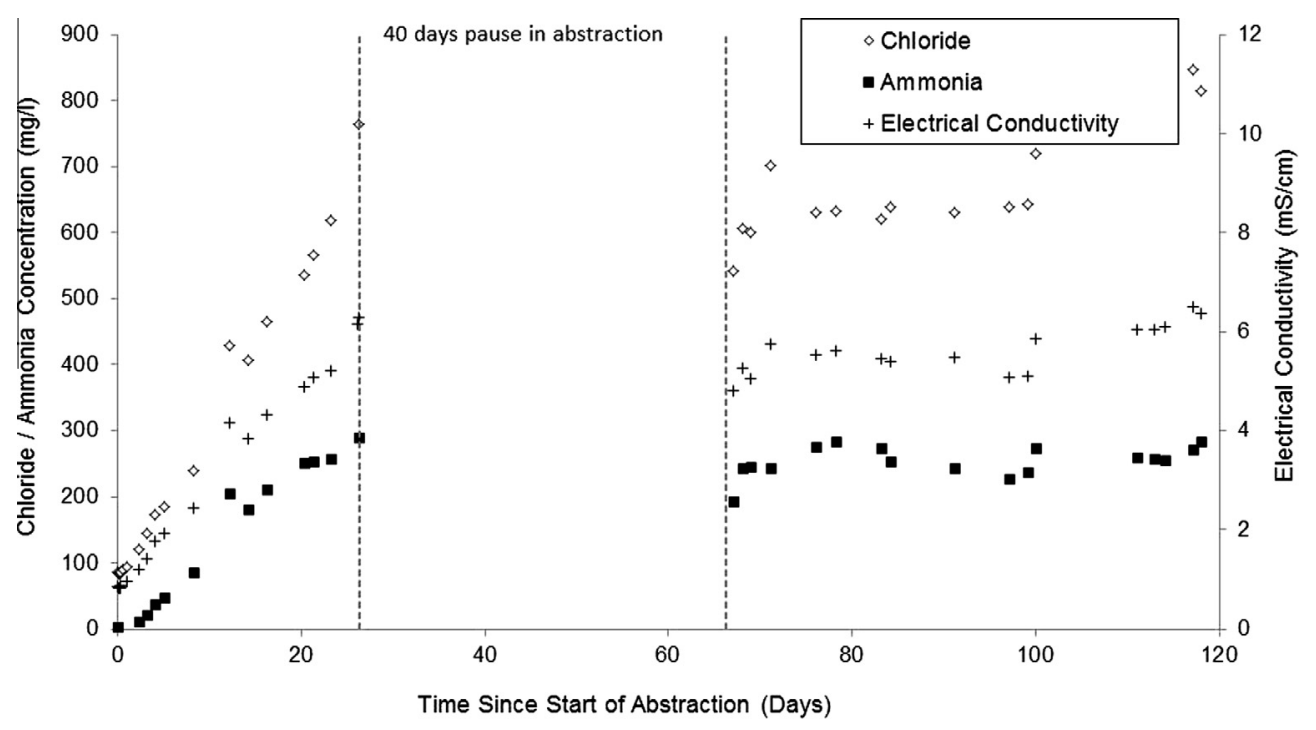

Fig. 10. Indigenous contaminant concentrations measured during abstraction.

(2011, 2012), but the main features are summarised as follows. $800 \mathrm{~m}^{3}$ of clean water with added tracers of potassium bromide $(\mathrm{Br})$ and a rhodamine dye (RWT) was injected evenly into the basal drainage system at a constant rate of $2 \mathrm{~m}^{3} / \mathrm{h}$ over a period of 17 days. This resulted in a uniform increase in the leachate level across the pilot by an average of $2.2 \mathrm{~m}$. Following a short pause of 2 days, the introduced tracer was pumped out of the basal drainage system (using the same infrastructure used to inject it) at a controlled rate $\left(1 \mathrm{~m}^{3} / \mathrm{h}\right.$ and later $\left.0.5 \mathrm{~m}^{3} / \mathrm{h}\right)$ over the following 120 days, which included a 40 day pause for site operational reasons.

Concentrations of both the introduced tracers and chemical parameters characteristic of landfill leachates (e.g. ammonia, chloride and electrical conductivity) were obtained from samples taken from the water pumped from the cell. As Figs. 9 and 10 demonstrate, at the start of pumping, the removed water was predominantly the introduced tracer, characterised by high $\mathrm{Br}$ and RWT concentrations, and low EC. As time progressed there was more of a mixing between the introduced tracer and the leachate already present within the landfill. Concentrations of EC, chloride and ammonia at the end of the pumping period (Fig. 10), are considered to be dominated by the average leachate composition in the landfill.

A plot of concentration versus time (e.g. Fig. 9), referred to as a 'break back curve' (BBC), was successfully fitted to a numerical model to calculate contaminant transport parameters for the BBC from the different tracers and indigenous contaminants (Rees-White et al., in preparation). The model used was a one dimensional model (DP-PULSE- Barker et al., 2000; Fretwell et al., 2005) that simulated advection and dual-porosity exchange (i.e. neglecting mechanical dispersion). A key parameter revealed by the model is the characteristic diffusion time of an immobile block of waste. In the Landgraaf cell, these values are indicative of immobile block sizes of at least $20-50 \mathrm{~cm}$. Contaminants held in these immobile blocks were to a large extent unaffected by flow occurring in the surrounding preferential flow paths .

\subsubsection{Conclusions on hydrology in bioreactors}

During the project strong indications were obtained that moisture flow through the waste follows preferential flow paths. The 
difference between composition of leachate in the basal drain and in the piezometers (see Section 5.3.1) fits expectations, when a dual porosity flow system is adopted. The same goes for the variation in leachate concentrations upon discontinuous operation of leachate operation (see Section 5.3.2). Geo-electric sounding does not result in clear identification of preferential channels. However the results do indicate that conditions within the waste are not homogeneous, most likely due to differences in moisture content and composition (see Section 5.3.3). A tracer test undertaken at the end of the operational period resulted in a clear conclusion that part of the waste contaminants are held in immobile blocks which interact by diffusion with flow occurring in the surrounding preferential flow paths (Section 5.3.4).

\subsection{Impact of biostabilisation on leaching behaviour}

\subsubsection{Leaching tests performed}

pH dependence tests (CEN/TS 14429) and the upflow percolation test (NEN 7373, quite similar to TS14405) were performed on an aggregated sample of both the fresh waste and the final residue upon excavation. In addition, batch leaching tests (EN 12457-4, 48 h equilibration time) were performed on 20 individual samples taken upon excavation. The results of the batch tests of the individual samples are an indication of the variability in leaching behaviour at the wastes own $\mathrm{pH}$. Results of the percolation tests are summarised in Table 7 . For selected components, results of $\mathrm{pH}$ dependence tests and batch leaching tests are presented in Fig. 11. Full results are given in the digital appendix. In general, the data show quite consistent $\mathrm{pH}$-dependent leaching patterns when the leaching behaviour of fresh and treated waste are compared.

\subsubsection{Some components explained}

The DOC leaching shows a substantial and consistent decrease after treatment over the whole range of $\mathrm{pH}$ values of about a factor $2-3$. In case of DOC variation between samples was limited.
The leaching of Ba shows little effect of treatment, since results for fresh and treated material is very similar. This observation was also made for several other elements (As, Mg, Sb, Zn, not shown). It is quite remarkable that almost the same results are obtained in a heterogeneous material after almost ten years in the landfill. Apparently, the chemical processes leading to release are consistent and did not change over time. Probably, the leaching of these elements is controlled by solubility control with inorganic minerals.

The leaching of $\mathrm{Cr}$ decreased almost a factor 10. Again, the batch test results of the individual samples after treatment show a good consistency with the $\mathrm{pH}$-stat results and the variation in the results is rather limited. $\mathrm{Cr}$ leaching seems to be dominated by the complexation with DOC in the $\mathrm{pH}$ range from 6 to 12 . Therefore, it is concluded that the degradation of DOC has a direct effect on the reduction of $\mathrm{Cr}$ leaching from this material.

The leaching of $\mathrm{Cu}$ in the $\mathrm{pH}$ dependence tests indicate a consistent reduction in emission after treatment. In case of $\mathrm{Cu}$, the batch test data from the individual samples show a substantial variation in emission. The leaching of $\mathrm{Cu}$ is probably dominated by complexation to DOC as is suggested by several authors (Dijkstra et al., 2004; van der Sloot et al., 2001). In addition, there are indications that the redox conditions within the waste can also influence $\mathrm{Cu}$ solubility (van Zomeren et al., 2007; van Zomeren and van der Sloot, 2006) The effect of redox conditions on Cu solubility might be explained by possible changes in the valence of $\mathrm{Cu}$, under field condition, where $\mathrm{Cu}(\mathrm{I})$ is formed which probably has a low affinity for DOC complexation, while $\mathrm{Cu}(\mathrm{II})$ exists under more oxidizing conditions and is known to have a high affinity for DOC complexation.

\subsubsection{Evaluation of leaching behaviour}

The percolation test is also prescribed in the EU Landfill Directive (EU, 1999) method to evaluate the possible emission of selected contaminants from waste. So the results in Table 7 might also be used to speculate whether bioreactor treatment has

Table 7

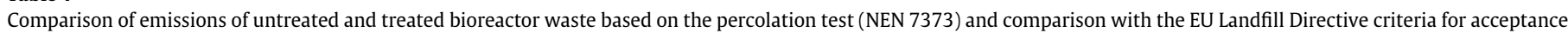

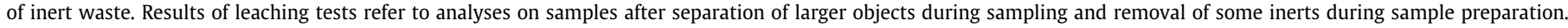

\begin{tabular}{|c|c|c|c|c|c|c|}
\hline Substance & $\begin{array}{l}\text { Emissions in } \mathrm{mg} / \mathrm{kg} \\
\text { Untreated }\end{array}$ & Treated & $\begin{array}{l}\text { EU LFD inert } \\
(\mathrm{mg} / \mathrm{kg})\end{array}$ & $\begin{array}{l}\text { Reduction } \\
(\%)\end{array}$ & $\begin{array}{l}\text { Leachate composition in } \\
2007(\mathrm{mg} / \mathrm{l})\end{array}$ & $\begin{array}{l}\mathrm{C}_{0} \text { EU LFD } \\
(\mathrm{mg} / \mathrm{l})\end{array}$ \\
\hline $\mathrm{Al}$ & 0.83 & 0.45 & & 50 & & \\
\hline As & 0.086 & 0.067 & 0.5 & 20 & 0.14 & 0.06 \\
\hline $\mathrm{Ba}$ & 1.3 & 1.8 & 20 & -40 & 0.53 & 4 \\
\hline $\mathrm{Ca}$ & 3300 & 550 & & 80 & & \\
\hline $\mathrm{Cd}$ & 0.035 & 0.003 & 0.04 & 90 & 0.001 & 0.02 \\
\hline $\mathrm{Cl}$ & 2000 & 940 & 800 & 50 & 1250 & 460 \\
\hline Co & 0.30 & 0.10 & & 70 & & \\
\hline $\mathrm{Cr}$ & 0.17 & 0.073 & 0.5 & 60 & 0.23 & 0.1 \\
\hline $\mathrm{Cu}$ & 0.93 & 0.2 & 2 & 80 & 0.16 & 0.6 \\
\hline $\mathrm{Fe}$ & 370 & 4.5 & & 99 & & \\
\hline K & 1500 & 750 & & 50 & & \\
\hline $\mathrm{Mg}$ & 470 & 210 & & 60 & & \\
\hline $\mathrm{Mn}$ & 37 & 2.0 & & 95 & & \\
\hline Mo & 2.4 & 2.9 & 0.5 & -20 & 0.022 & 0.2 \\
\hline $\mathrm{Ni}$ & 2.2 & 1.8 & 0.4 & 20 & 0.18 & 0.12 \\
\hline $\mathrm{Pb}$ & 0.11 & 0.14 & 0.5 & -30 & 0.055 & 0.15 \\
\hline $\mathrm{Sb}$ & 0.13 & 0.17 & 0.06 & -30 & 0.010 & 0.1 \\
\hline Se & 0.074 & 0.09 & 0.1 & -20 & 0.010 & 0.004 \\
\hline $\mathrm{Si}$ & 110 & 300 & & -160 & & \\
\hline Sn & 0.04 & 0.023 & & 40 & & \\
\hline $\mathrm{SO}_{4}$ & $5700^{\mathrm{a}}$ & 2500 & 1000 & 60 & 114 & 1500 \\
\hline $\mathrm{Sr}$ & 17.8 & 5.2 & & 70 & & \\
\hline $\mathrm{Ti}$ & 0.015 & 0.013 & & 10 & & \\
\hline V & 0.0055 & 0.011 & & -100 & & \\
\hline $\mathrm{Zn}$ & 3.7 & 3.0 & 4 & 20 & 0.14 & 1.2 \\
\hline DOC & 4300 & 950 & 500 & 80 & 440 & 160 \\
\hline
\end{tabular}

\footnotetext{
a Calculated from total $S$ analysed by ICP.
} 
(a)

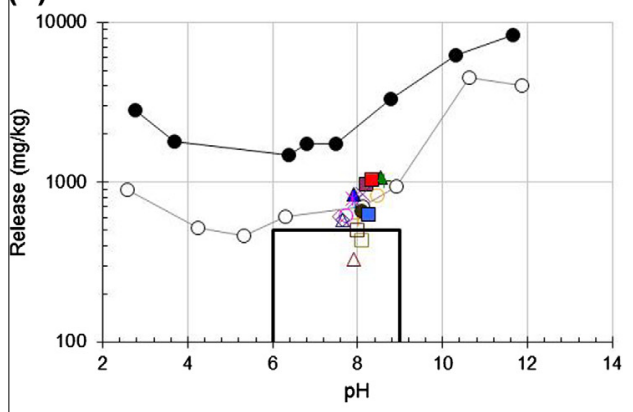

(c)

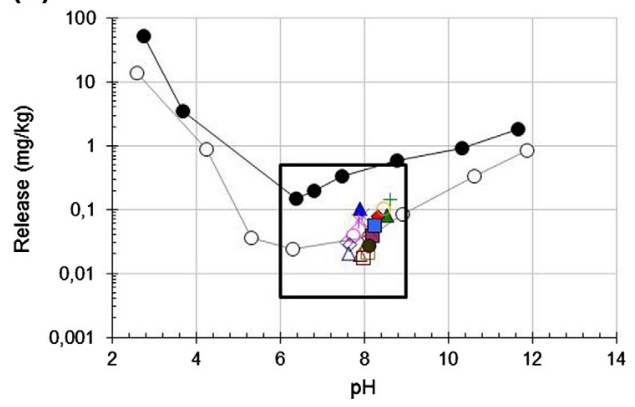

(b)

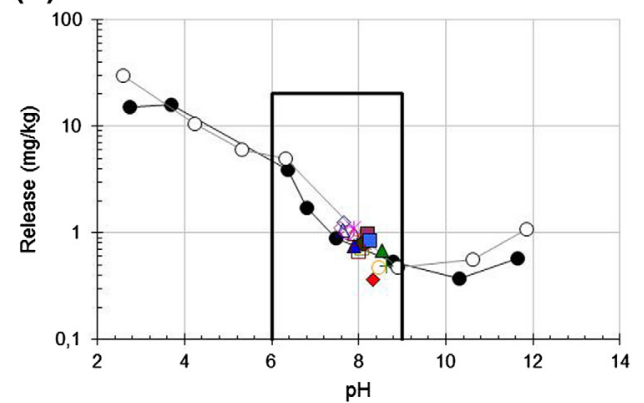

(d)

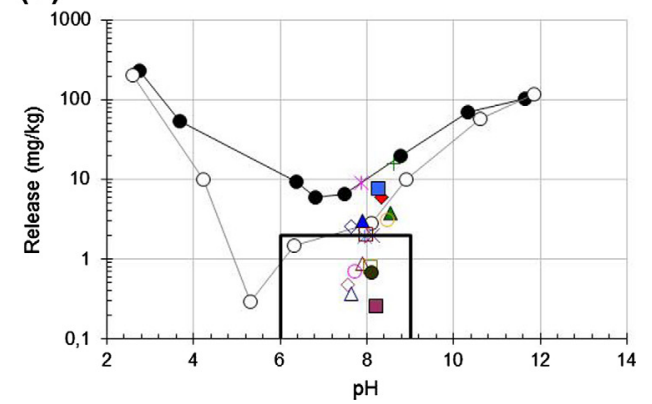



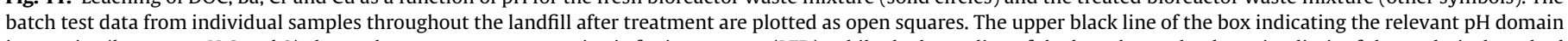

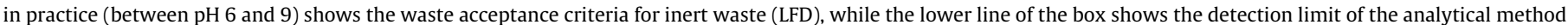
(if relevant).

resulted in waste of acceptable quality. Emissions of $\mathrm{As}, \mathrm{Ba}, \mathrm{Cr}, \mathrm{Cu}$ and $\mathrm{Pb}$ are lower (both before and after treatment) than the acceptance criteria for inert waste. The leaching of $\mathrm{Cd}$ in fresh waste is around the limit value and decreased substantially after treatment to below the limit value. Chloride and DOC emissions substantially reduce to levels around the limit value. The leaching of Se and $\mathrm{Zn}$ do not change drastically and exhibit values around the limit values for acceptance of inert waste. Leaching of $\mathrm{Mo}, \mathrm{Ni}, \mathrm{Sb}$ and $\mathrm{SO}_{4}$ remain well above the limit values after treatment. The leaching of $\mathrm{SO}_{4}$ is reduced by a factor 2 . The other elements are not substantially influenced. For $\mathrm{Ni}$ and $\mathrm{Zn}$ this is a surprise, because they are known to form DOC-complexes. So reduction in leaching of $\mathrm{DOC}$ is expected to result in a reduction in leaching of $\mathrm{Ni}$ and $\mathrm{Zn}$ (van Zomeren et al., 2006). The high metals content of the waste in general (due to large amounts of shredder waste) and oversaturation of DOC's binding activity for metals might be an explanation for this.

Another possible evaluation of the bioreactors performance is the comparison of leachate quality (data from year 2007) with the maximum concentration $\left(C_{0}\right)$ that would have been allowed from a percolation test, as defined in the Landfill Directive (Table 7). This assessment provides rather similar conclusions as the evaluation of the cumulative release. However, the leachate concentrations in 2007 appeared higher than the $C_{0}$ concentration limit of the Landfill Directive for As and $\mathrm{Cr}$, while the laboratory test results indicated a release below the limit value.

The comparison of waste acceptance criteria with emissions from a landfill is not fully justified, it provides a means to estimate whether the emissions are close to established limit values. However, a next step in the environmental assessment could be to use the percolation test results as a source term in a model scenario to estimate the long term release at a point of compliance. This development is currently ongoing in the Netherlands in a joint research program of the Sustainable Landfill Foundation and the Ministry of Infrastructure and Environment.

\section{Conclusions}

The main objective of the test-cell was to demonstrate that the biodegradation of waste can be accelerated and completed within a relative short term. Following 4 years of leachate recirculation, gas generation and anaerobic conversion of the waste appeared to be largely completed. After two more years of aeration the cell was excavated. Samples of the final residue in the cell indicated that the residual amount of biodegradable organic material was comparable with the residue of a well aerated landfill. Respiration and gas production of the residue meets the standards that are proposed in Germany for landfill aftercare to be considered completed.

Enhanced biodegradation resulted in a material with a significantly reduced leaching potential for DOC. Since DOC helps mobilise some heavy metals, enhanced biodegradation also resulted in a reduced leaching potential of the heavy metals $\mathrm{Cd}, \mathrm{Co}, \mathrm{Cr}$ and $\mathrm{Cu}$.

At present there are no criteria available that define quality objectives for waste residues in bioreactors that would result in reduced aftercare measures being acceptable. In the EU, criteria are defined for inert waste (Annex II to the Landfill Directive), which were compared against the residue recovered from the bioreactor at the end of the tests. The bioreactor end-product did not meet the criteria for $\mathrm{DOC}, \mathrm{Cl}^{-}, \mathrm{SO}_{4}^{2-}$, and specific metals such as $\mathrm{Sb}, \mathrm{As}$, $\mathrm{Cr}, \mathrm{Ni}$ and $\mathrm{Mb}$. This can for a part be attributed to the fact that Annex II criteria were not taken into account during design and operation. E.g. DOC and $\mathrm{Cl}^{-}$can still be significantly reduced by increased flushing of the cell. So there seems to be room for improvement of bioreactor performance here.

The system for leachate recirculation worked well. A high recirculation rate was maintained for long times, and there was no evidence of any deterioration of the leachate injection and collection systems. Flow through the waste, however, was demonstrated to follow preferential flow paths, since a tracer test undertaken at the end of the operational period indicated that a dual porosity model fitted the tracer test data well. A conclusion was that part 
of the waste contaminants are held in immobile blocks which interact by diffusion with flow occurring in the surrounding preferential flow paths.

Aeration resulted in an increase in COD and constant $\mathrm{N}_{\mathrm{kj}}$ concentrations in leachate. Long term aeration is often described a method to improve leachate quality. An initial increase in concentrations is in line with observations elsewhere. The two years' time period of aeration in this project seems to be too short to verify claims on significant reduction of COD and $\mathrm{N}_{\mathrm{kj}}$ concentrations in the longer term (6-10 years).

\section{Appendix A. Supplementary material}

Supplementary data associated with this article can be found, in the online version, at http://dx.doi.org/10.1016/j.wasman.2013.03. 003.

\section{References}

Barker, J.A., Wright, T., Fretwell, B.A., 2000. A pulsed-velocity method of double porosity solute transport modelling. In: Dassargues (Ed.), International Conference on Tracers and Modelling in Hydrogeology. IAHS, Liège, Belgium.

Barlaz, M.A., Bareither, C.A., Hossain, A., Saquing, J., Mezzari, I., Benson, C.H., Tolaymat, T.M., Yazdani, R., 2010. Performance of North American bioreactor landfills: II. Chemical and biological characteristics. Journal of Environmental Engineering 136 (8), 839-853.

Beaven, R., 2009. A challenge to modellers to predict the performance of a landfill cell. In: Sardinia 2009, Twelfth International Waste Management and Landfill Symposium. S. Margherita di Pula, Cagliari, Italy.

Beaven, R.P., Hudson, A.P., Barker, J.A., 2003. Description of a tracer test through waste and application of a DP model. In: Sardinia 2003, 9th International Waste Management and Landfill Symposium, October 2003. Santa Margherita di Pula, Cagliari, Sardinia.

Beaven, R.P., Hudson, A.P., Knox, K., Powrie, W., Robinson, J.P., 2013. Clogging of landfill tyre and aggregate drainage layers by methanogenic leachate and implications for practice. Waste Management 33, 431-444. http://dx.doi.org/ 10.1016/j.wasman.2012.10.021.

Dijkstra, J.J., Meeussen, J.C.L., Comans, R.N.J., 2004. Leaching of heavy metals from contaminated soils; an experimental and modelling study. Environmental Science and Technology 38, 4390-4395.

EU, 1999. Council directive 1999/31/EC of 26 April 1999 on the landfill of waste. Official Journal of the European Communities, 16-7-1999, pp. L182/1-L182/19.

Fretwell, B.A., Burgess, W.G., Barker, J.A., Jefferies, N.L., 2005. Redistribution of contaminants by a fluctuating water table in a micro-porous, double-porosity aquifer: field observations and model simulations. Journal of Contaminant Hydrology 78, 27-52.

Hoekstra, N., Kruiver, P., Kers, H., van Vossen, W., Woelders, H., Oonk, H., 2009. Throwing light into black boxes: using new characterization tools for risk assessment of abandoned landfills. In: Sardinia 2009, 12th International Waste Management and Landfill Symposium, October 2009. Santa Margherita di Pula, Cagliari, Sardinia.

Jolly, J.M., Beaven, R.P., Barker, R.D., 2011. Resolution of electrical imaging of fluid movement in landfills. Proceedings of the ICE - Waste and Resource Management 164 (2), 79-96. http://dx.doi.org/10.1680/warm.2011.164.2.79.

Klink, R.E., Ham, R.K., 1982. Effects of moisture movement on methane production in solid waste landfill samples. Resources and Conservation, 29-41.

Laner, D., Fellner, J., Brunner, P.H., 2011. Future landfill emissions and the effect of final cover installation - a case study. Waste Management 31 (7), 1522-1531.

Oonk, H., 2012. Efficiency of landfill gas collection for methane emission reduction. Greenhouse Gas Measurement and Management 2 (2-3), 129-145.
Oonk, H., Woelders, H., 1999. Full-scale demonstration of treatment of mechanically separated organic residue in a bioreactor at VAM in Wijster. Waste Management and Research 17 (6), 535-542.

Oonk, H., Coops, O., van Tienen, T., Vedelaar, A.J., Woelders, H., Welling, F., 2004. Stimulering Van Stortgasvorming Door Percolaatinfiltratie: Twee Demonstraties (stimulation of the production of landfill gas by means of recirculation of leachate, two demonstration projects, Elspeet and Wijster, Report in Dutch). TNO-report 2004/376, TNO, Apeldoorn.

Rees-White, T.C., Beaven, R.P., Woelders, H., Beaumont, T., Hannen, M., Marsman, A 2011. Preliminary results of a fill and draw flushing test in a pilotscale landfill cell. In: Sardinia 2011, 13th International Waste Management and Landfill Symposium, 3-7 October 2011. Santa Margherita di Pula, Cagliari, Sardinia.

Rees-White, T.C., Beaven, R.P., Woodman, N., Barker, J.A., 2012. A 'Fill and Draw' Tracer test at the Landgraaf Landfill Pilot November 2010 to March 2011 University of Southampton WMRG technical report, <http://eprints.soton.ac.uk/ 349326/>.

Ritzkowski, M., 2011. How does landfill aeration impact on leachate composition? In: Sardinia 2011, 13th International Waste Management and Landfill Symposium, 3-7 October 2011. Santa Margherita di Pula, Cagliari, Sardinia.

Ritzkowski, M., Stegmann, R., 2008. In situ Belüftung der Altdeponie Kuhstedt Ergebnisse eines 8-jährigen BMBF-Vorhabens. In: Deponietechnik 2008, Hamburger Berichte 31, Verlag Abfall aktuell, pp. 31-54, ISBN 3-9810064-6-1.

Rosqvist, H., Destouni, G., 2000. Solute transport through preferential pathways in municipal solid waste. Journal of Contaminant Hydrology 46, 39-60.

Stegmann, R., Heyer, K.U., Hupe, K., Willand, A., 2006. Deponienachsorge Handlungsoptionen, Dauer, Kosten und quantitative Kriterien für die Entlassungaus der Nachsorge, IFAS Ingenieurbüro für Abfallwirtschaft Prof. R. Stegmann und Partner, Hamburg, Germany.

Sloot, H.A., van der, Rietra, R.P.J.J., Vroon, R., Scharff, H., Woelders, J.A., 2001. Similarities in the long term leaching behaviour of predominantly inorganic waste, MSWI bottom ash, degraded MSW and bioreactor residues. In: Eighth International waste management and landfill symposium. CISA Environmental Sanitary Engineering Centre, Cagliari, Italy, S. Margherita di Pula, Cagliari, Italy, pp. 199-208.

Vossen, W. van, Heijer, K.U., 2009. Feasibility study pilot project sustainable emission reduction at the existing landfills Kragge and Wieringermeer in the Netherlands. Preliminary design and cost-estimate of the technical measures infiltration and aeration to enhance stabilization at the landfill Kragge, report with reference: 9T6764/R00002/500080/DenB, Royal Haskoning, Den Bosch, The Netherlands.

van Zomeren, A., van der Sloot, H.A., Meeussen, J.C.L., Jacobs, J., Scharff, H., 2007. Prediction of the long-term leaching behaviour of a sustainable landfill containing predominantly inorganic waste. In: Haarstrick, A., Reichel, T. (Eds.), Landfill Modelling. CISA Publisher, Padova.

Wang, X., Padgett, J.M., De la Cruz, F.B., Barlaz, M.A., 2011. Wood biodegradation in laboratory-scale landfills. Environmental Science and Technology 45 (16), 6864-6871.

Wens, P., Vercauteren, T., De Windt, W., Verstraete, W., 2001. Factors inhibiting anaerobic degradation in a landfill. In: Proceedings Sardinia 2001, Eighth International Waste Management and Landfill Symposium. Cagliari, Italy, October 1-5, 2001. T, vol. I, pp. 13-20.

White, J.K., Beaven, R.P., 2013. Developments to a landfill processes model following its application to two landfill modelling challenges. Waste Management 33, 1969-1981. <http://dx.doi.org/10.1016/j.wasman.2012.12.006>.

Yazdani, R, Kieffer, J., Sananikone, K., Augenstein, D., 2006. Full scale bioreactor landfill for carbon sequestration and greenhouse emission control, final report, Award No. DE-FC26-01NT41152, US Department of Energy, Washington, DC.

Zomeren, A. van, van der Sloot, H.A., 2006. Equifill, Landfill Site for Predominantly Inorganic Waste. Dutch Sustainable Landfill Foundation. 's-Hertogenbosch, the Netherlands.

Zomeren, A. van, Meeussen, H., Oonk, H., Luning, L., van der Sloot, H.A., 2006 Basisdocument Database: Evaluation of Geochemical and Biochemical Processes and Release from Landfills. Dutch Sustainable Landfill foundation. 's-Hertogenbosch, the Netherlands. 


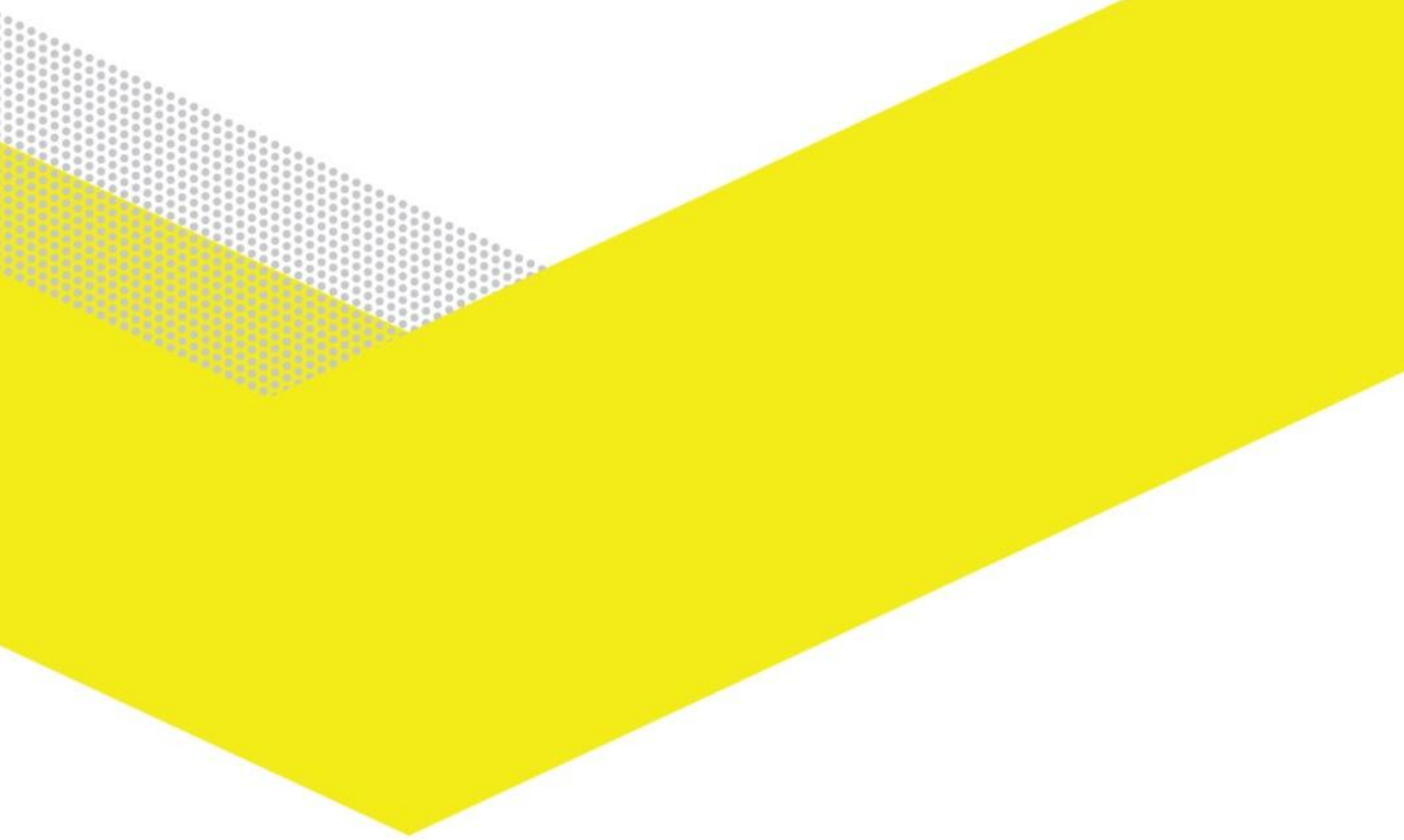

ECN

Westerduinweg 3

P.O. Box 1

1755 LE Petten

1755 LG Petten

The Netherlands

The Netherlands

$T+31885154949$

$F+31885158338$

info@ecn.nl

www.ecn.nl 